\title{
A Preliminary Report Showing Spinosad and Fluralaner Are Able to Incapacitate Cimex lectularius L., the Common Bed Bug
}

Johnathan M. Sheele ${ }^{1}$

1. Emergency Medicine, Mayo Clinic, Jacksonville, USA

Corresponding author: Johnathan M. Sheele, sheele.johnathan@mayo.edu

\begin{abstract}
Cimex lectularius L., the common bed bug, is a hematophagous human ectoparasite. The veterinary drugs, spinosad and fluralaner, were studied for their ability to incapacitate $C$. lectularius when administered in a blood meal using an artificial feeding system under laboratory conditions. Tested drug doses were based on the reported peak blood levels in animals given the drugs. Spinosad at doses $1,000 \mathrm{ng} / \mathrm{mL}$ or higher resulted in $75 \%$ or greater bed bug incapacitation (defined as death or immobility). Fluralaner at doses $500 \mathrm{ng} / \mathrm{mL}$ or higher had $100 \%$ bed bug incapacitation. Both drugs were significantly more effective than controls at these doses $(P<0.001)$.
\end{abstract}

Categories: Miscellaneous, Infectious Disease, Public Health

Keywords: bed bug, cimex lectularius, fluralaner, spinosad, bedbug, drug, treatment, veterinary, xenointoxication

\section{Introduction}

Cimex lectularius L., known as the common bed bug, is an obligate hematophagous insect that primarily feeds on humans [1]. The number of bed bug infestations has risen in many parts of the world in the past few decades, which is in part due to growing resistance to the pesticides used in their control [1]. Elimination of bed bug infestations relies on an integrated pest management (IPM) approach that includes decreasing insect harborage and the use of pesticides or heat treatments [1].

Under natural conditions, bed bugs take blood meals every few days [1]. Eggs laid by female C. lectularius hatch after about 1 week, with the first instars then seeking a blood meal [1]. Bed bugs develop through five instars before becoming sexually active adults [1].

Bed bugs are likely one of the most common human ectoparasites encountered by health care providers in industrialized countries [2-9]. No orally administered pharmaceutical agents for humans have a US Food and Drug Administration-approved indication for bed bugs. The antiparasitic drugs, ivermectin and moxidectin, both cause toxicity to bed bugs [10-15]. Ivermectin could be considered an adjective therapy along with IPM to eliminate a bed bug infestation. Moxidectin has more favorable pharmacokinetics than ivermectin, but the drug does not appear to cause as much long-lasting harm to bed bugs as ivermectin [11,16].

Received 12/02/2019

Review began 12/08/2019 Review ended 01/22/2020 Published 04/03/2020

\section{(c) Copyright 2020}

Sheele. This is an open access article distributed under the terms of the Creative Commons Attribution License CC-BY 4.0., which permits unrestricted use, distribution, and reproduction in any medium, provided the original author and source are credited.
The veterinary drugs, spinosad and fluralaner, are currently used to control ectoparasites in animals but have not been studied for activity against bed bugs when administered in a blood meal. Spinosad, which consists of spinosyn A and D, is used to kill fleas in dogs and cats by acting at the nicotinic acetylcholine receptors in the insect nervous system [17]. Ingestion of $30 \mathrm{mg} / \mathrm{kg}$ of spinosad by dogs resulted in a peak plasma concentration of $1,550 \mathrm{ng} / \mathrm{mL}$ about 3 hours after ingestion, with a mean elimination half-life of 271 hours [18]. Spinosad has low mammalian toxicity, with an oral median lethal dose of $3,738 \mathrm{mg} / \mathrm{kg}$ for male rats and greater than $5,000 \mathrm{mg} / \mathrm{kg}$ for female rats and mice [17]. Topically applied spinosad has been shown to be toxic to bed bugs [19].

Fluralaner is part of the isoxazoline class of ectoparasiticides that inhibits the glutamate and gammaaminobutyric acid ligand-gated chloride channels [20]. Fluralaner has high plasma protein binding and volume of distribution, which allows for therapeutic concentrations in animals for up to 12 weeks [20]. A single dose of afoxolaner, a drug in the same class as fluralaner, was 100\% efficacious at clearing Sarcoptes scabiei (scabies) in a porcine model of human scabies [21]. In dogs, the peak plasma concentration after ingesting $25 \mathrm{mg} / \mathrm{kg}$ fluralaner varied by whether the animal was fasting $(1,591 \mathrm{ng} / \mathrm{mL})$ or fed $(3,377 \mathrm{ng} / \mathrm{mL})$ [22]. In animals, the time to peak concentration was approximately 1 day, with mean plasma concentrations greater than $500 \mathrm{ng} / \mathrm{mL}$ persisting for more than 21 days after drug dosing [22]. The aim of this study was to determine if blood meals containing fluralaner and spinosad would incapacitate C. lectularius.

\section{Materials And Methods}

Mixed inbreeding populations of the Fort Dix-Harlan strain and Ridge strain of C. lectularius L. were used in 


\section{Cureus}

the experiments. The numbers of nymphs and adult bed bugs were not held constant, to mimic a natural population. Bed bugs were prepared and fed as described previously $[11,12,15]$. Bed bugs were kept in 2-mL microcentrifuge tubes containing a piece of paper on which the insects gathered (Figure 1).

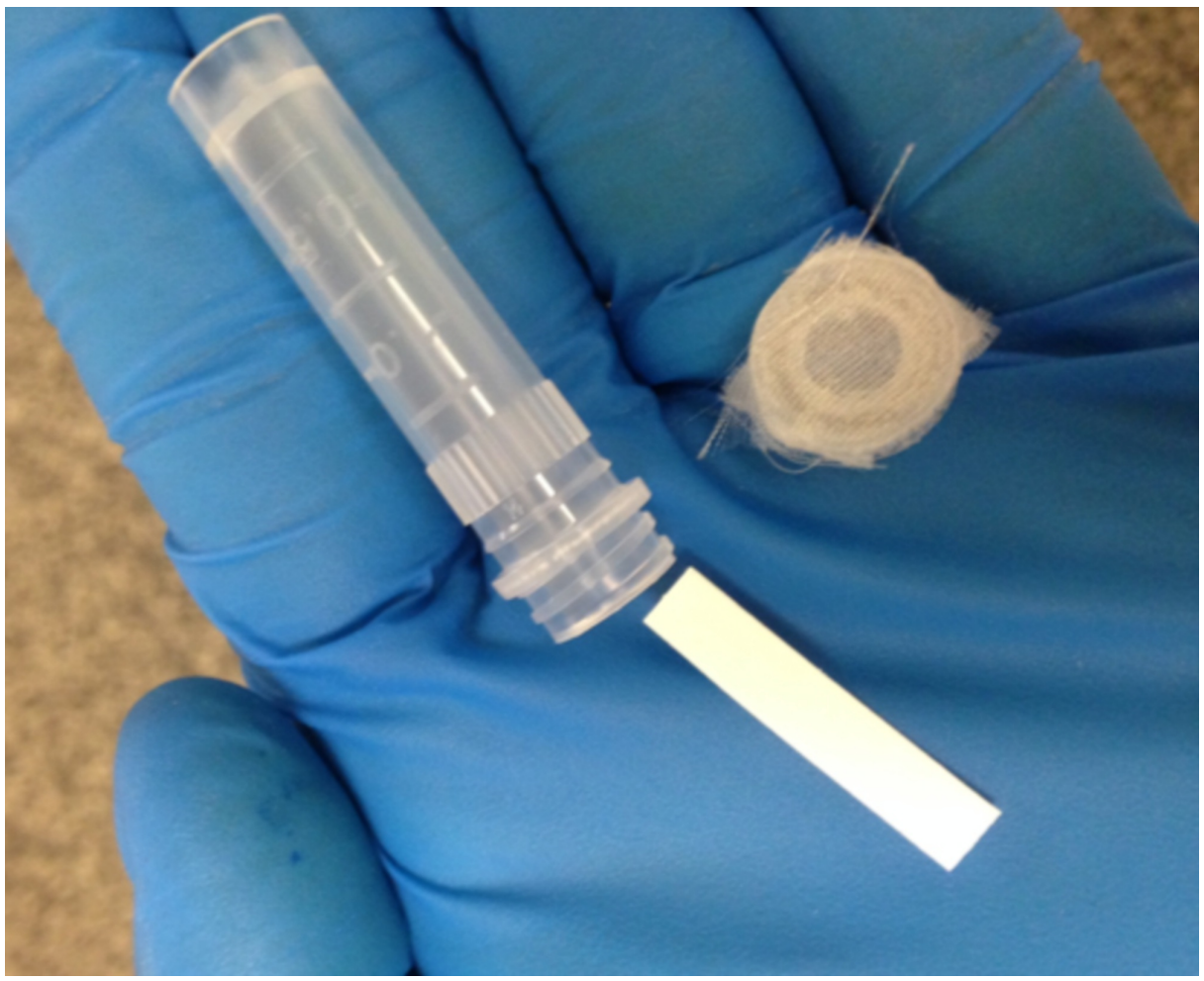

\section{FIGURE 1: An example of a test tube that would contain the bed bugs}

A 1/4-inch hole was drilled in the top of each centrifuge tube cap, and a piece of sheer fabric was glued to the surface, which was then covered with parafilm (Figure 2). Inverting this tube into warm blood allowed the bed bugs to feed (Figure 2).

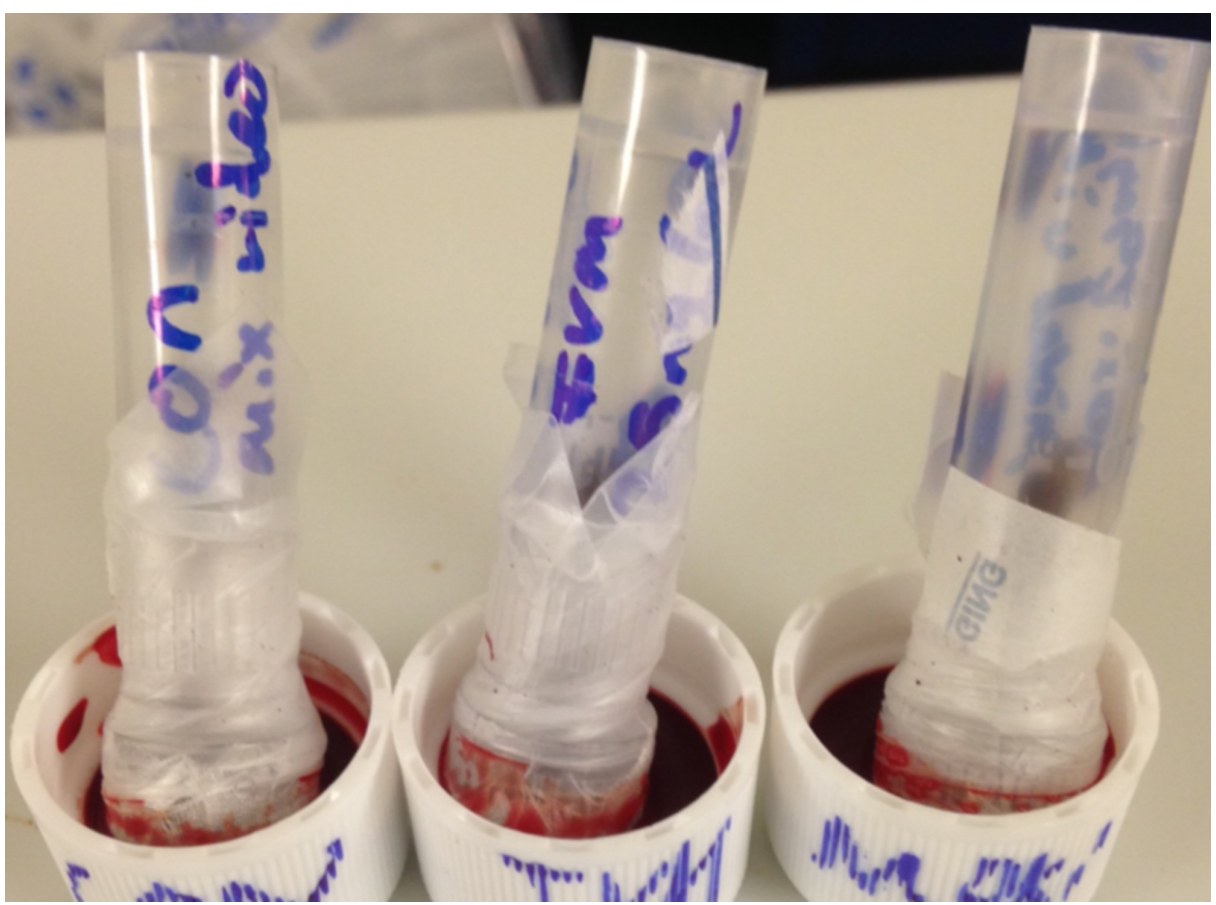

FIGURE 2: An example of bed bugs feeding on warmed blood 


\section{Cureus}

Unfed bed bugs were removed and discarded. Fed C. lectularius were kept and observed, and all bed bugs fed only once (Figure 3).

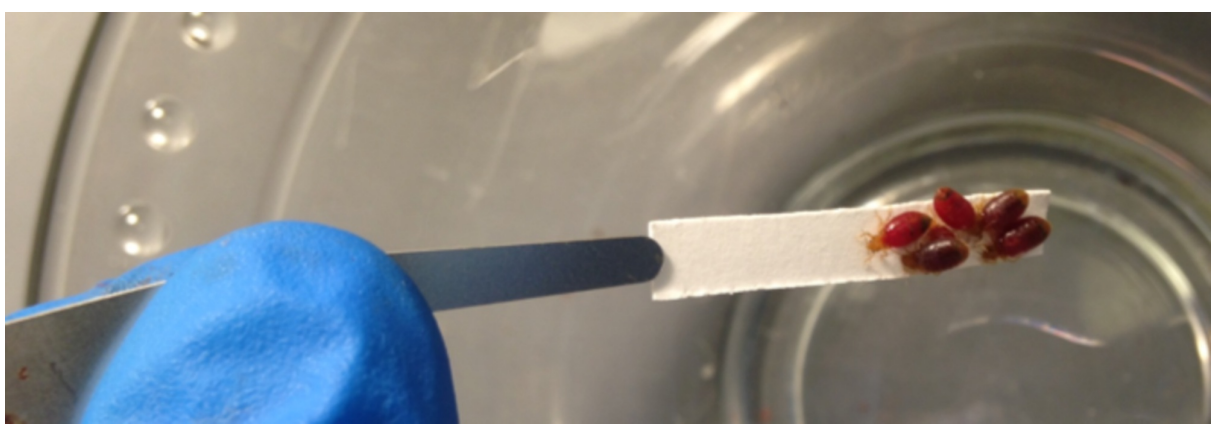

FIGURE 3: An example of fed bed bugs

Spinosad was purchased from Toronto Research Chemicals and diluted to a stock concentration of 2.63 $\mathrm{mg} / \mathrm{mL}$ with dimethyl sulfoxide (DMSO). Fluralaner was purchased from Cayman Chemicals and diluted to a stock concentration of $10 \mathrm{mg} / \mathrm{mL}$ with DMSO. For experiment 1 , the stock drug was further diluted with DMSO to the correct concentration such that 2 microliters of drug were added to $1.998 \mathrm{~mL}$ of defibrinated sheep's blood (Hemostat Laboratories) to achieve the final desired concentration. For controls, 2 microliters of DMSO was added to $1.998 \mathrm{~mL}$ of defibrinated sheep's blood. Observations were made after the bed bug feeding on day 0 and incapacitation rates were recorded on days 7 and 22 post-feeding.

DMSO has previously been reported to have bed bug toxicity [12]. To minimize DMSO toxicity, experiments 2 and 3 were performed with 2 microliters of the stock drugs diluted with Hanks's Buffered Salt Solution (HBBS) to a concentration such that when $10 \mathrm{mcL}$ of the diluted drug was added to $1.990 \mathrm{~mL}$ of defibrinated sheep's blood the final drug concentration was achieved. For controls, 10 microliters of DMSO was diluted 1:5,000 in HBSS and added to $1.990 \mathrm{~mL}$ of defibrinated sheep's blood. Bed bug incapacitation rates were recorded on days four and 14 for experiment 2 and on days two and 14 for experiment 3 . Bed bugs were recorded as being either an adult or nymph throughout experiment 2 . The life stages for each insect used in experiment 3 were not recorded. All experiments had two control groups, which were combined for the analysis.

The primary endpoint was bed bug incapacitation, which was defined as insects that were dead, largely immobile, or unable to remain attached to the paper perch inside the tube. The incapacitation rate (No. of incapacitated insects/No. of fed insects in the group) for each drug dose was compared with the incapacitation rate in the control group for each time point. Differences in the incapacitation rates of spinosad and fluralaner were compared to the corresponding incapacitation rates in the control group and assessed for statistical significance using a comparison of proportions calculator

(https://www.medcalc.org/calc/comparison_of_proportions.php). Statistical significance was set at $P<0.05$.

\section{Results}

There were a total of 917 fed C. lectularius used in the three experiments including 387 for experiment 1, 207 for experiment 2 , and 413 for experiment 3 . The percentage of nymphs in each feeding group in experiment 1 ranged between $81 \%$ and $96 \%$ and $81 \%$ and $96 \%$ for experiment 2 .

\section{Experiment 1}

The number and life stage for all fed C. lectularius are listed in Table 1 . All bed bugs, with the exception of the controls and fluralaner $10 \mathrm{ng} / \mathrm{mL}$, were incapacitated within hours of the feeding (Table 1). 


\section{Cureus}

\begin{tabular}{|c|c|c|c|c|c|c|c|c|c|}
\hline & Male & Female & $\begin{array}{l}5^{\text {th }} \\
\text { instar }\end{array}$ & $\begin{array}{l}4^{\text {th }} \\
\text { instar }\end{array}$ & $\begin{array}{l}3^{\text {rd }} \\
\text { instar }\end{array}$ & $\begin{array}{l}2^{\text {nd }} \\
\text { instar }\end{array}$ & $\begin{array}{l}1^{\text {st }} \\
\text { instar }\end{array}$ & $\begin{array}{l}\text { Total number of fed } \mathrm{C} \text {. } \\
\text { lectularius }\end{array}$ & $\begin{array}{l}\% \text { nymphs in fed } \\
\text { population }\end{array}$ \\
\hline Control & 8 & 3 & 2 & 10 & 26 & 27 & 7 & 83 & 87 \\
\hline $\begin{array}{l}\text { Spinosad 5,000 } \\
\mathrm{ng} / \mathrm{mL}^{*}\end{array}$ & 4 & 0 & 1 & 7 & 8 & 3 & 1 & 24 & 83 \\
\hline $\begin{array}{l}\text { Spinosad } 1,000 \\
\mathrm{ng} / \mathrm{mL}^{*}\end{array}$ & 3 & 3 & 2 & 4 & 10 & 5 & 5 & 32 & 81 \\
\hline $\begin{array}{l}\text { Spinosad } 500 \\
\mathrm{ng} / \mathrm{mL}^{*}\end{array}$ & 2 & 1 & 3 & 5 & 12 & 10 & 15 & 48 & 94 \\
\hline $\begin{array}{l}\text { Spinosad } 100 \\
\mathrm{ng} / \mathrm{mL}^{*}\end{array}$ & 1 & 2 & 5 & 5 & 6 & 4 & 3 & 26 & 88 \\
\hline $\begin{array}{l}\text { Fluralaner 5,000 } \\
\mathrm{ng} / \mathrm{mL}^{*}\end{array}$ & 3 & 3 & 2 & 1 & 6 & 7 & 9 & 31 & 81 \\
\hline $\begin{array}{l}\text { Fluralaner 1,000 } \\
\mathrm{ng} / \mathrm{mL}^{*}\end{array}$ & 5 & 2 & 2 & 4 & 6 & 6 & 15 & 40 & 83 \\
\hline $\begin{array}{l}\text { Fluralaner } 500 \\
\mathrm{ng} / \mathrm{mL}^{*}\end{array}$ & 1 & 1 & 2 & 6 & 10 & 8 & 19 & 47 & 96 \\
\hline $\begin{array}{l}\text { Fluralaner } 100 \\
\mathrm{ng} / \mathrm{mL}^{*}\end{array}$ & 4 & 3 & 3 & 5 & 9 & 6 & 9 & 39 & 82 \\
\hline $\begin{array}{l}\text { Fluralaner } 10 \\
\mathrm{ng} / \mathrm{mL}\end{array}$ & 6 & 0 & 0 & 1 & 4 & 3 & 3 & 17 & 65 \\
\hline
\end{tabular}

\section{TABLE 1: Life stages of $C$. lectularius used in experiment 1}

${ }^{*}$ All incapacitated within hours of feeding

On day 7 post-feeding, the incapacitation rate was $28 \%$ in the control group, $58 \%$ in the spinosad $100 \mathrm{ng} / \mathrm{mL}$ group, and $100 \%$ in the spinosad $500,1,000$, and $5,000 \mathrm{ng} / \mathrm{mL}$ groups (Table 2). It was $100 \%$ in the fluralaner at $10,100,500,1,000$, and $5,000 \mathrm{ng} / \mathrm{mL}$ groups (Table 2). All doses were significantly different than those

from the control group $(\mathrm{p}<0.01$; Table 2$)$. Some insects were able to advance their life stage over the course of the week (e.g. 5th instar controls). 


\section{Cureus}

\begin{tabular}{|c|c|c|c|c|c|c|c|}
\hline & Adult & $5^{\text {th }}$ instar & $4^{\text {th }}$ instar & $3^{\text {rd }}$ instar & $2^{\text {nd }}$ instar & $1^{\text {st }}$ instar & Total incapacitation \\
\hline Control & $11 / 11$ & $7 / 2^{*}$ & $6 / 10$ & $20 / 26$ & $9 / 27$ & $7 / 7$ & $28 \%$ \\
\hline Spinosad 5,000 ng/mL & $0 / 4$ & $0 / 1$ & $0 / 7$ & $0 / 8$ & $0 / 3$ & $0 / 1$ & $100 \%(p<0.001)$ \\
\hline Spinosad 1,000 ng/mL & $0 / 6$ & $0 / 2$ & $0 / 4$ & $0 / 10$ & $0 / 5$ & $0 / 5$ & $100 \%(p<0.001)$ \\
\hline Spinosad $500 \mathrm{ng} / \mathrm{mL}$ & $0 / 3$ & $0 / 3$ & $0 / 5$ & $0 / 12$ & $0 / 10$ & $0 / 15$ & $100 \%(p<0.001)$ \\
\hline Spinosad $100 \mathrm{ng} / \mathrm{mL}$ & $3 / 3$ & $1 / 5$ & $4 / 5$ & $2 / 6$ & $0 / 4$ & $1 / 3$ & $58 \%(P=0.005)$ \\
\hline Fluralaner $5,000 \mathrm{ng} / \mathrm{mL}$ & $0 / 6$ & $0 / 2$ & $0 / 1$ & $0 / 6$ & $0 / 7$ & $0 / 9$ & $100 \%(p<0.001)$ \\
\hline Fluralaner $1,000 \mathrm{ng} / \mathrm{mL}$ & $0 / 7$ & $0 / 2$ & $0 / 4$ & $0 / 6$ & $0 / 6$ & $0 / 15$ & $100 \%(p<0.001)$ \\
\hline Fluralaner $500 \mathrm{ng} / \mathrm{mL}$ & $0 / 2$ & $0 / 2$ & $0 / 6$ & $0 / 10$ & $0 / 8$ & $0 / 19$ & $100 \%(p<0.001)$ \\
\hline Fluralaner $100 \mathrm{ng} / \mathrm{mL}$ & $0 / 7$ & $0 / 3$ & $0 / 5$ & $0 / 9$ & $0 / 6$ & $0 / 9$ & $100 \%(p<0.001)$ \\
\hline Fluralaner $10 \mathrm{ng} / \mathrm{mL}$ & $0 / 6$ & $0 / 0$ & $0 / 1$ & $0 / 4$ & $0 / 3$ & $0 / 3$ & $100 \%(p<0.001)$ \\
\hline
\end{tabular}

TABLE 2: Incapacitation rates day 7 post-feeding (number of healthy $C$. lectularius at that life stage/number of fed $C$. lectularius on day 0 ) for experiment 1

*indicates that over 7 days more 4 th instars became 5 th instars than were originally fed 5 th instars

On day 22 post-feeding, the incapacitation rate was $61 \%$ in the control group, $88 \%$ in the spinosad 100 $\mathrm{ng} / \mathrm{mL}$ group, and $100 \%$ in the spinosad $500,1,000$, and $5,000 \mathrm{ng} / \mathrm{mL}$ groups (Table 3$)$. It was $100 \%$ in the fluralaner 10, 100, 500, 1,000, and 5,000 ng/mL groups (Table 3). All doses were significantly different than the control $(\mathrm{p}<0.05)$ (Table 3). The high mortality rates in the control group were likely due to DMSO toxicity, and even with high mortality in the control groups, bed bug mortality rates in the spinosad and fluralaner groups were all significantly higher.

\begin{tabular}{|c|c|c|c|c|c|c|}
\hline & Adults & Adult incapacitation rate & Nymphs & Nymph incapacitation rate & Eggs & Total incapacitation \\
\hline Control & $5 / 11$ & $29 \%$ & $8 / 72$ & $69 \%$ & 0 & $61 \%$ \\
\hline Spinosad 5,000 ng/mL & $0 / 4$ & $100 \%$ & $0 / 20$ & $100 \%$ & 0 & $100 \%(p<0.001)$ \\
\hline Spinosad 1,000 ng/mL & $0 / 6$ & $100 \%$ & $0 / 26$ & $100 \%$ & 0 & $100 \%(p<0.001)$ \\
\hline Spinosad 500 ng/mL & $0 / 3$ & $100 \%$ & $0 / 45$ & $100 \%$ & 0 & $100 \%(p<0.001)$ \\
\hline Spinosad $100 \mathrm{ng} / \mathrm{mL}$ & $3 / 3$ & $0 \%$ & $0 / 23$ & $100 \%$ & 0 & $88 \%(P=0.03)$ \\
\hline Fluralaner $5,000 \mathrm{ng} / \mathrm{mL}$ & $0 / 6$ & $100 \%$ & $0 / 25$ & $100 \%$ & 0 & $100 \%(p<0.001)$ \\
\hline Fluralaner $1,000 \mathrm{ng} / \mathrm{mL}$ & $0 / 7$ & $100 \%$ & $0 / 33$ & $100 \%$ & 0 & $100 \%(p<0.001)$ \\
\hline Fluralaner $500 \mathrm{ng} / \mathrm{mL}$ & $0 / 2$ & $100 \%$ & $0 / 45$ & $100 \%$ & 0 & $100 \%(p<0.001)$ \\
\hline Fluralaner $100 \mathrm{ng} / \mathrm{mL}$ & $0 / 7$ & $100 \%$ & $0 / 32$ & $100 \%$ & 0 & $100 \%(p<0.001)$ \\
\hline Fluralaner $10 \mathrm{ng} / \mathrm{mL}$ & $0 / 6$ & $100 \%$ & $0 / 11$ & $100 \%$ & 0 & $100 \%(p<0.001)$ \\
\hline
\end{tabular}

TABLE 3: Incapacitation rates 22 days post-feeding (number of healthy $C$. lectularius at that life stage/number of fed $\mathrm{C}$. lectularius on day 0 ) for experiment 1

\section{Experiment 2}

Table 4 shows the number of fed C. lectularius and whether they were adults or nymphs. 


\section{Cureus}

\begin{tabular}{|c|c|c|c|c|}
\hline & Adults & Nymphs & Total number of fed C. lectularius & \% Nymphs in fed population \\
\hline Control & 15 & 42 & 57 & 74 \\
\hline Spinosad $100 \mathrm{ng} / \mathrm{mL}$ & 7 & 18 & 25 & 72 \\
\hline Spinosad $10 \mathrm{ng} / \mathrm{mL}$ & 5 & 29 & 34 & 85 \\
\hline Fluralaner 10 ng/mL & 4 & 29 & 35 & 83 \\
\hline Fluralaner 1 ng/mL & 8 & 16 & 25 & 64 \\
\hline Fluralaner $0.1 \mathrm{ng} / \mathrm{mL}$ & 8 & 23 & 31 & 74 \\
\hline
\end{tabular}

TABLE 4: Life stages of fed C. lectularius used in experiment 2

Four days post-feeding, the incapacitation rate for spinosad $100 \mathrm{ng} / \mathrm{mL}$ was $8 \%$, spinosad $10 \mathrm{ng} / \mathrm{mL}$ was $18 \%$, fluralaner $10 \mathrm{ng} / \mathrm{mL}$ was $9 \%$, fluralaner $1 \mathrm{ng} / \mathrm{mL}$ was $0 \%$, and fluralaner $0.1 \mathrm{ng} / \mathrm{mL}$ was $10 \%$ which were all not significantly different $(p>0.05)$ than the control group which was $9 \%$ (Table 5). Some insects were able to advance their life stage after the feeding and before incapacitation was determined (e.g. fluralaner 1 $\mathrm{ng} / \mathrm{mL}$ exposed adults).

\begin{tabular}{|c|c|c|c|}
\hline & Incapacitation rate for Adults & Incapacitation rate for nymphs & Total incapacitation rate \\
\hline Control & $11 / 15$ & $41 / 42$ & $9 \%$ \\
\hline Spinosad $100 \mathrm{ng} / \mathrm{mL}$ & $8 / 7^{\star}$ & 15/18 & $8 \% \quad(p=0.88)$ \\
\hline Spinosad 10 ng/mL & $4 / 5$ & $24 / 29$ & $18 \%(p=0.21)$ \\
\hline fluralaner $10 \mathrm{ng} / \mathrm{mL}$ & $3 / 4$ & $29 / 29$ & $9 \%(p=1.0)$ \\
\hline fluralaner $1 \mathrm{ng} / \mathrm{mL}$ & $9 / 8$ & $16 / 16$ & $0 \%(p=0.12)$ \\
\hline fluralaner $0.1 \mathrm{ng} / \mathrm{mL}$ & $8 / 8$ & $20 / 23$ & $10 \%(p=0.88)$ \\
\hline
\end{tabular}

TABLE 5: Incapacitation rate for fed bed bugs in experiment 2, four days post-feeding (number of healthy $\mathrm{C}$. lectularius/number of originally fed $\mathrm{C}$. lectularius on day 0 )

*indicates that there was one more insect categorized as an adult, rather than a nymph, 4 days post-feeding

Fourteen days post-feeding, the incapacitation rate for spinosad $100 \mathrm{ng} / \mathrm{mL}$ was $20 \%$, spinosad $10 \mathrm{ng} / \mathrm{mL}$ was $38 \%$, fluralaner $10 \mathrm{ng} / \mathrm{mL}$ was $17 \%$, fluralaner $1 \mathrm{ng} / \mathrm{mL}$ was $20 \%$, and fluralaner $0.1 \mathrm{ng} / \mathrm{mL}$ was $29 \%$ which were all not significantly different $(p>0.05$ ) than the control group which was $28 \%$ (Table $)$ ). Eggs and 1 st instars were present in all treatment groups (Table 6). 


\section{Cureus}

\begin{tabular}{|c|c|c|c|c|c|}
\hline & $\begin{array}{l}\text { Incapacitation rate } \\
\text { for Adults }\end{array}$ & $\begin{array}{l}\text { Incapacitation rate } \\
\text { for Nymphs }\end{array}$ & $\begin{array}{l}\text { Total } \\
\text { incapacitation } \\
\text { rate }\end{array}$ & $\begin{array}{l}\text { Total number of } \\
\text { eggs laid }\end{array}$ & $\begin{array}{l}\text { New } 1^{\text {st }} \text { instars joining } \\
\text { population }\end{array}$ \\
\hline Control & 10/15 & $31 / 42$ & $28 \%$ & 16 & 9 \\
\hline $\begin{array}{l}\text { Spinosad } 100 \\
\mathrm{ng} / \mathrm{mL}\end{array}$ & $8 / 7$ & $12 / 18$ & $20 \%(p=0.44)$ & 2 & 2 \\
\hline $\begin{array}{l}\text { Spinosad } 10 \\
\mathrm{ng} / \mathrm{mL}\end{array}$ & $4 / 5$ & $17 / 29$ & $38 \%(p=0.32)$ & 7 & 3 \\
\hline $\begin{array}{l}\text { Fluralaner } 10 \\
\mathrm{ng} / \mathrm{mL}\end{array}$ & $3 / 4$ & $26 / 29$ & $17 \%(p=0.23)$ & 1 & 1 \\
\hline $\begin{array}{l}\text { Fluralaner } 1 \\
\mathrm{ng} / \mathrm{mL}\end{array}$ & $8 / 8$ & $12 / 16$ & $20 \%(p=0.45)$ & 8 & 4 \\
\hline $\begin{array}{l}\text { Fluralaner } 0.1 \\
\mathrm{ng} / \mathrm{mL}\end{array}$ & $8 / 8$ & $14 / 23$ & $29 \% \quad(p=0.92)$ & 8 & 4 \\
\hline
\end{tabular}

TABLE 6: Life stages of fed bed bugs used in experiment 2, 14 days post-feeding (number of healthy $\mathrm{C}$. lectularius/number of originally fed C. lectularius on day $\mathbf{0}$ )

\section{Experiment 3}

On day 2 , the post-feeding incapacitation rate was $18 \%$ in the spinosad $100 \mathrm{ng} / \mathrm{mL}$ group, $56 \%$ in the spinosad $500 \mathrm{ng} / \mathrm{mL}$ group, $78 \%$ in the spinosad $1,000 \mathrm{ng} / \mathrm{mL}$ group, and $100 \%$ in the spinosad $5,000 \mathrm{ng} / \mathrm{mL}$ group which were all significantly different than the incapacitation rate of $3 \%$ in the control group $(p<0.05$ for all; Table 7). The incapacitation rate for fluralaner was $61 \%$ in the $100 \mathrm{ng} / \mathrm{mL}$ group and $100 \%$ for fluralaner 500, 1,000, and 5,000 ng/mL groups which were significantly different from the control $(p<0.001$ for all; Table 7). On day 14 , the post-feeding incapacitation rate was $13 \%$ in the spinosad $100 \mathrm{ng} / \mathrm{mL}$ group, $44 \%$ in the spinosad $500 \mathrm{ng} / \mathrm{mL}$ group, $76 \%$ in the spinosad $1,000 \mathrm{ng} / \mathrm{mL}$ group, and $100 \%$ in the spinosad $5,000 \mathrm{ng} / \mathrm{mL}$ group. The incapacitation rates for spinosad $500 \mathrm{ng} / \mathrm{mL}, 1,000 \mathrm{ng} / \mathrm{mL}$, and 5,000 ng/mL were all significantly different from the control group, respectively $(p<0.05$ for all; Table 7$)$. The incapacitation rate for fluralaner was $49 \%$ in the $100 \mathrm{ng} / \mathrm{mL}$ group and $100 \%$ for fluralaner $500,1,000$, and 5,000 $\mathrm{ng} / \mathrm{mL}$ groups which were significantly different than the control ( $p<0.001$ for all; Table 7$)$.

\begin{tabular}{|c|c|c|c|}
\hline & Number of fed C. lectularius & Day 2 incapacitation rate & Day 14 incapacitation rate \\
\hline Control & 90 & $3 \%$ & $14 \%$ \\
\hline Spinosad 5,000 ng/mL & 37 & $100 \%(p<0.001)$ & $100 \%(p<0.001)$ \\
\hline Spinosad 1,000 ng/mL & 45 & $78 \%(p<0.001)$ & $76 \%(p<0.001)$ \\
\hline Spinosad 500 ng/mL & 39 & $56 \%(p<0.001)$ & $44 \%(p<0.001)$ \\
\hline Spinosad 100 ng/mL & 38 & $18 \%(p=0.003)$ & $13 \%(p=0.88)$ \\
\hline Fluralaner $5,000 \mathrm{ng} / \mathrm{mL}$ & 28 & $100 \%(p<0.001)$ & $100 \%(p<0.001)$ \\
\hline Fluralaner $1,000 \mathrm{ng} / \mathrm{mL}$ & 35 & $100 \%(p<0.001)$ & $100 \%(p<0.001)$ \\
\hline Fluralaner $500 \mathrm{ng} / \mathrm{mL}$ & 50 & $100 \%(p<0.001)$ & $100 \%(p<0.001)$ \\
\hline Fluralaner $100 \mathrm{ng} / \mathrm{mL}$ & 51 & $61 \%(p<0.001)$ & $49 \%(p<0.001)$ \\
\hline
\end{tabular}

TABLE 7: Incapacitation rates for fed bed bugs used in experiment 3 on days 2 and 14 postfeeding

The incapacitation rates when experiments 2 and 3 were combined are shown in Figure 4 for spinosad and Figure 5 for fluralaner. 


\section{Cureus}

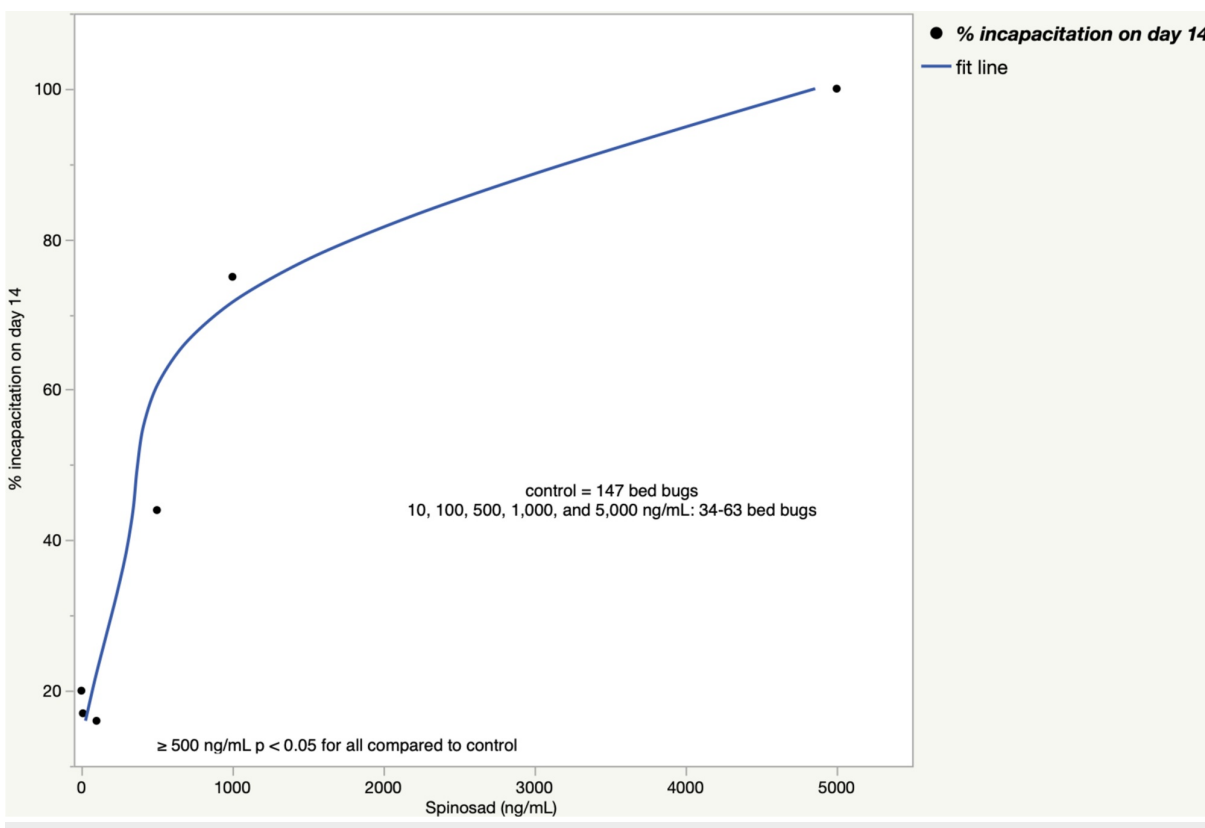

FIGURE 4: Bed bug incapacitation rate 14 days after a spinosad blood meal (experiments 2+3)

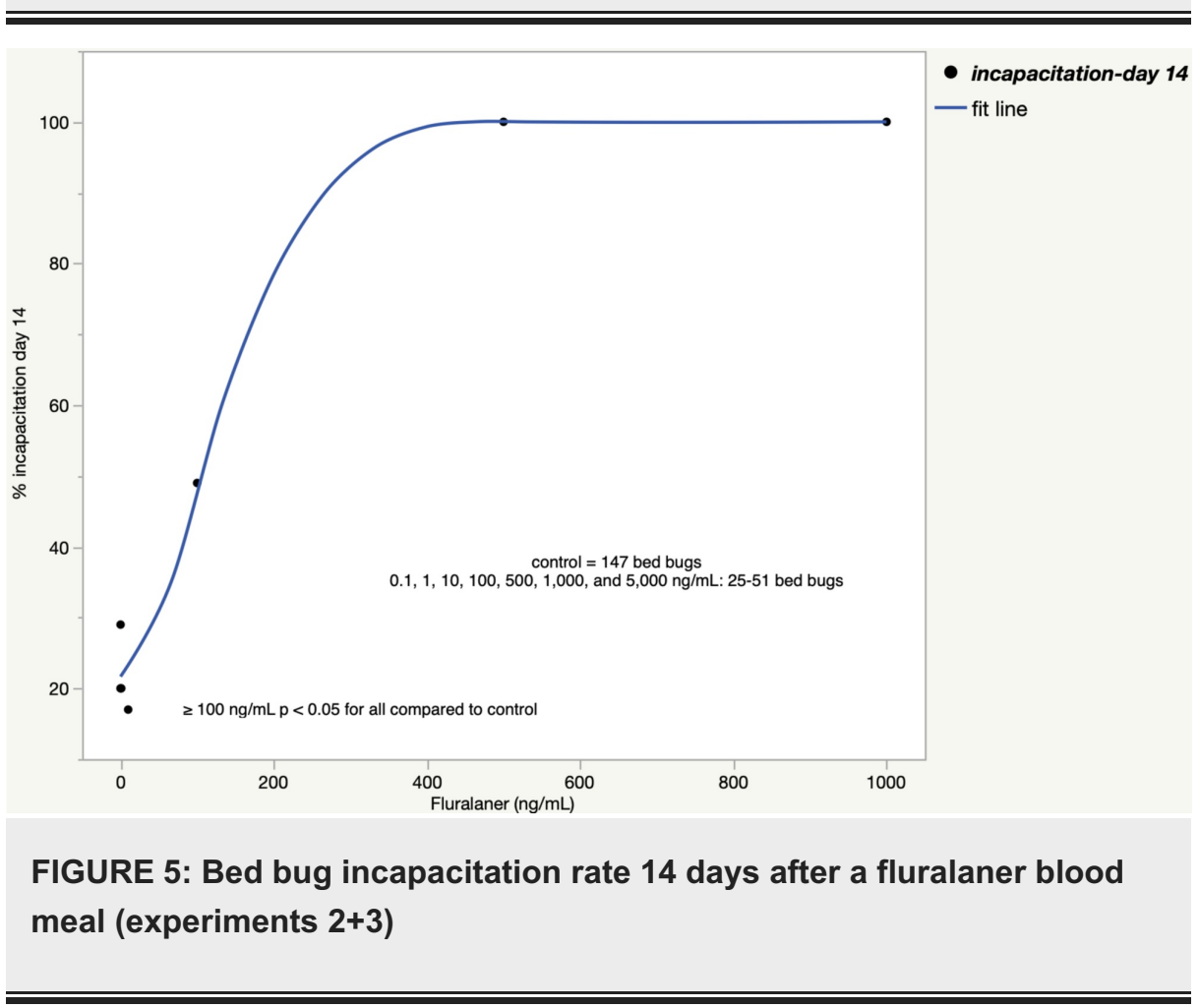

\section{Discussion}

Both spinosad and fluralaner showed a dose-response effect on C. lectularius incapacitation. At $\geqslant 500 \mathrm{ng} / \mathrm{mL}$, fluralaner incapacitated all fed bed bugs. The results are preliminary and additional studies are needed to further explore the toxic effects these drugs have on bed bugs. Future studies could include administering the drugs to animals, measuring the plasma concentrations of the drugs in the animals, and simultaneously observing the $C$. lectularius morbidity and mortality over time for each life stage in the fed insects.

If spinosad was ever to be used as an oral chemotherapeutic agent in humans, and the pharmacokinetics are similar in humans as in dogs, then the plasma concentration of spinosad would be less than $500 \mathrm{ng} / \mathrm{mL}$ within 1 day [18]. If spinosad was ever to be used by humans to help control a bed bug infestation, it would likely mean that multiple doses of the drug would be required. 
Fluralaner has a much longer plasma half-life than spinosad [17-18,20-22]. A single dose of fluralaner in dogs resulted in plasma concentrations greater than $500 \mathrm{ng} / \mathrm{mL}$ for more than 21 days [22]. If the pharmacokinetics of fluralaner in dogs are similar in humans, this could mean that a person could take a single oral dose of fluralaner and would have over two weeks of plasma concentrations that achieved $100 \%$ bed bug incapacitation in our experiments which could be sufficient time for all bed bugs in a population to take a toxic blood meal [22].

Fluralaner also rapidly kills Phlebotomus sand flies and Anopheles, Culex, and Aedes mosquitoes [23-25]. Preclinical modeling estimates that one oral $410 \mathrm{mg}$ dose of fluralaner in humans would provide 50 to 90 days of insecticidal effect against Phlebotomus sand flies and mosquitoes [25]. However, there have been no human clinical trials of oral fluralaner or spinosad reported in clinicaltrials.gov or published in PUBMED.gov. There is only one case report of an intentional overdose of spinosad [26]. If fluralaner is ever shown to be safe, in humans it could then be further evaluated for its ability to harm C. lectularius.

\section{Limitations}

The number and life stages for the $C$. lectularius were not held constant at each of the tested doses. Additionally, the time from the laboratory feeding until the incapacitation rates were calculated was not constant. The experiments were not set up to examine fecundity, the ability of the insects to refeed, molt, or ambulate. Experiment 1, and to a lesser extent, experiments 2 and 3, had high mortality in the control group which is hypothesized to be secondary to DMSO. Differences between pyrethroid-sensitive and resistant bed bugs, as well as recently field-captured versus laboratory-raised insects, were not assessed.

The experimental design did not account for any drug metabolism or intracellular accumulation, which would otherwise occur in vivo, and so incapacitation rates for bed bugs fed on humans or animals, given spinosad or fluralaner, might be different than what was found in our laboratory feedings. Additionally, the doses that were used in the laboratory feedings were based on the plasma levels of the drugs recorded in animals given the drugs at therapeutic doses. However, hematophagous insects take whole blood meals and not plasma meals, and so the actual drug concentration obtained from a feeding insect would likely be different than what would be reported as the plasma concentration.

\section{Conclusions}

Preliminary results show that both spinosad and fluralaner are able to incapacitate C. lectularius in a doseresponsive manner. Doses of $\geqslant 500 \mathrm{ng} / \mathrm{mL}$ of fluralaner in spiked blood meals were able to incapacitate all $C$. lectularius. Doses of $\geqslant 1,000 \mathrm{ng} / \mathrm{mL}$ of spinosad in spiked blood meals were able to incapacitate a majority of C. lectularius. If either drug, but especially fluralaner due to its favorable pharmacokinetics and safety profile in animals, is approved for human use, then further studies should be undertaken to evaluate their ability to eliminate bed bug infestations.

\section{Additional Information \\ Disclosures}

Human subjects: All authors have confirmed that this study did not involve human participants or tissue. Animal subjects: All authors have confirmed that this study did not involve animal subjects or tissue. Conflicts of interest: In compliance with the ICMJE uniform disclosure form, all authors declare the following: Payment/services info: All authors have declared that no financial support was received from any organization for the submitted work. Financial relationships: All authors have declared that they have no financial relationships at present or within the previous three years with any organizations that might have an interest in the submitted work. Other relationships: All authors have declared that there are no other relationships or activities that could appear to have influenced the submitted work.

\section{Acknowledgements}

I thank Dr. Gale Ridge at the Connecticut Agricultural Experimental Station for providing the bed bugs.

\section{References}

1. Doggett SL, Dwyer DE, Peñas PF, Russell RC: Bed bugs: clinical relevance and control options. Clin Microbiol Rev. 2012, 25:164-92. 10.1128/CMR.05015-11

2. Sheele JM, Barrett E, Farhan O, Morris N: Analysis of bed bug (Cimex lectularius) introductions into an academic medical center. Infect Control Hosp Epidemiol. 217, 38:623-4. 10.1017/ice.2017.13

3. Sheele JM, Crandall CJ, Chang BF, Arko BL, Dunn CT, Negrete A: Characteristics of bed bug infested patients in the emergency department. Emerg Med Int. 2019, 2019:8721829. 10.1155/2019/8721829

4. Sheele JM, Gaines S, Maurer N, et al.: A survey of patients with bed bugs in the emergency department . Am J Emerg Med. 2017, 35:697-8. 10.1016/j.ajem.2016.12.076

5. Sheele JM, Mallipeddi N, Coppolino K, Chetverikova M, Mothkur S, Caiola C: FMC Verifi traps are not effective for quantifying the burden of bed bugs in an emergency department. Am J Infect Control. 2016, 44:1078-80. 10.1016/j.ajic.2016.02.013

6. Sheele JM, Crandall CJ, Chang BF, Arko BL, Dunn CT, Negrete A: Risk factors for bed bugs among urban 
emergency department patients. J Community Health. 2019, 44:1061-68. 10.1007/s10900-019-00681-2

7. Sheele JM, Crandall C, Chang BF, Arko BL, Dunn C, Negrete A: Cimicosis in persons previously fed upon by bed bugs. Cureus. 2019, 11:e5941. 10.7759/cureus.5941

8. Sheele JM, Barrett E, Dash D, Ridge GE: Analysis of the life stages of Cimex lectularius captured within a medical centre suggests that the true numbers of bed bug introductions are under-reported. J Hosp Infect. 2017, 97:310-312. 10.1016/j.jhin.2017.07.025

9. Totten V, Charbonneau H, Hoch W, Shah S, Sheele JM: The cost of decontaminating an ED after finding a bed bug: results from a single academic medical center. Am J Emerg Med. 2016, 34:649. 10.1016/j.ajem.2015.12.020

10. Ridge GE, Elmer W, Gaines S, Li X, Schlatzer D, McClure-Brinton K, Sheele JM: Xenointoxication of a rabbit for the control of the common bed bug Cimex lectularius L. using ivermectin.. Scientifica. 2019, 2019:4793569. 10.1155/2019/4793569

11. Sheele JM, Ridge GE: Toxicity and potential utility of ivermectin and moxidectin as xenointoxicants against the common bed bug, Cimex lectularius L.. Parasitol Res. 2016, 115:3071-81.

12. Sheele JM, Ridge GE, Du W, Mallipeddi N, Vallabhaneni M: A screen of pharmaceutical drugs for their ability to cause short-term morbidity and mortality in the common bed bug, Cimex lectularius L.. Parasitol Res. 2017, 116:2619-26. 10.1007/s00436-017-5565-0

13. Ostlind DA, Cifelli S, Conroy JA, Mickle WG, Ewanciw DV, Andriuli FJ, Ho P: A novel Cimex lectularius (Hemiptera; Cimicidae)-rodent assay for the detection of systemic ectoparasiticide activity. Southwestern Entomol. 2001, 26:181-86.

14. Sheele JM, Anderson JF, Tran TD, Teng YA, Byers PA, Ravi BS, Sonenshine DE: Ivermectin causes Cimex lectularius (bedbug) morbidity and mortality. J Emerg Med. 2013, 45:433-40. 10.1016/j.jemermed.2013.05.014

15. Sheele JM, Ridge G, Li X, Schlatzer D, Lesser E: The benefit of a single oral dose of ivermectin in humans: the adverse effects on Cimex lectularius L.. Cureus. 2019, 11:e6098. 10.7759/cureus.6098

16. Zha C, Wang C, Sheele JM: Effect of moxidectin on bed bug feeding, development, fecundity, and survivorship. Insects. 2017, 8:106.

17. Stebbins KE, Bond DM, Novilla MN, Reasor MJ: Spinosad insecticide: subchronic and chronic toxicity and lack of carcinogenicity in CD-1 mice. Toxicol Sci. 2002, 65:276-87. 10.1093/toxsci/65.2.276

18. Dunn ST, Hedges L, Sampson KE, Lai Y, Mahabir S, Balogh L, Locuson CW: Pharmacokinetic interaction of the antiparasitic agents ivermectin and spinosad in dogs. Drug Metab Dispos. 2011, 39:789-95. 10.1124/dmd.110.034827

19. Hamm RL, Tolley MP, Chin-Heady E, Foard T: Toxicity of selected insecticides (spinosad, spinetoram, and isoclast active [sulfoxaflor]) to bed bugs, 2005 and 2009. Arthropod Manag Tests. 2015, 40:1-2.

20. Sojka PA: Isoxazolines. J Exot Pet Med. 2018, 27:118-122.

21. Bernigaud C, Fang F, Fischer K, et al.: Efficacy and pharmacokinetics evaluation of a single oral dose of afoxolaner against Sarcoptes scabiei in the porcine scabies model for human infestation. Antimicrob Agents Chemother. 2018, 62:e02334-17. 10.1128/AAC.02334-17

22. Walther FM, Allan MJ, Roepke RK, Nuernberger MC: The effect of food on the pharmacokinetics of oral fluralaner in dogs. Parasit Vectors. 2014, 7:84. 10.1186/1756-3305-7-84.

23. Gomez SA, Picado A: Systemic insecticides used in dogs: potential candidates for phlebotomine vector control?. Trop Med Int Health. 2017, 22:755-764.

24. Loza A, Talaga A, Herbas G, et al.: Systemic insecticide treatment of the canine reservoir of Trypanosoma cruzi induces high levels of lethality in Triatoma infestans, a principal vector of Chagas disease. Parasit Vectors. 2017, 10:344. 10.1186/s13071-017-2278-2

25. Miglianico M, Eldering M, Slater H, et al.: Repurposing isoxazoline veterinary drugs for control of vectorborne human diseases. Proc Natl Acad Sci USA. 2018, 115:E6920-6. 10.1073/pnas.1801338115

26. Su TY, Lin JL, Lin-Tan DT, Tseng HH, Yen TH: Human poisoning with spinosad and flonicamid insecticides . Hum Exp Toxicol. 2011, 30:1878-81. 10.1177/0960327111401639 